\title{
ВИВЧЕННЯ ВПЛИВУ РАДІАЦІЙНОЇ СКЛАДОВОЇ НА ВЕЛИЧИНУ ЕФЕКТИВНОЇ ТЕПЛОПРОВІДНОСТІ КОМПОЗИТНО-ПОРИСТОГО МАСИВУ
}

\author{
Товажнянський Л. Л., член-кор. НАНУ, д-р техн. наук, професор, \\ Ведь В. Є., д-р техн. наук, професор, Миронов А. М., канд. техн. наук \\ Національний технічний університет «Харківський політехнічний інститут», м. Харків
}

\begin{abstract}
Анотація. В роботі розглянуто низку питань, пов'язаних з теплообмінними процесами, які відбуваються у промислових вуглевипалювальних установках. Дослідження спрямоване на пошук розрахункового алгоритму, який здатен еквівалентно врахувати вплив структури композитно-пористого тіла на коефіцієнт теплопровідності масиву, сформованого деревними полінцями у просторі вагонетки. Показано, щзо відома феноменологічна модель процесу теплопровідності, яка базується на концепиї суцільності твердих тіл, не придатна до використання у контексті розрахунку внеску ступеню пористості матеріалу до його теплопровідної здатності. Вказано, що подібна модель ігнорує не тільки структурну будову реальних матеріалів, але й можливість формування анізотропних кластерних утворень в їх товщі. Виявлено, щзо для масиву деревини, який приймає участь у виробництві деревного вугілля піролізним способом, спрощення мікроскопічної структури не припускається. Проаналізовано кілька способів завантаження деревної сировини у вагонетку та відсоток об'єму, щу може бути корисно використаний у кожному з них. Обрано найбільш технологічно та експлуатаційно доцільний спосіб завантаження деревної сировини. Розглянуто відому розрахункову модель, щзо базується на рівномірному розподілі твердої фази уздовж меж структурного елементу. Встановлено, що при межових значеннях подібна модель демонструє результати, що не відповідають фізичній дійсності. Виявлено причини неадекватності моделі реальним об'єктам на прикладі масиву деревних полін. Представлено вдосконалену розрахункову модель, щзо передбачає заміну лінійного контакту між елементами на поверхневий. Розглянуто штучні умови розрахункового припущення про те, щчо безкінечно тонкий прошарок матеріалу розташований уздовж меж структурного елементу, а уся маса матеріалу зосереджена у центрі в вигляді об'єкту квадратного перетину. Наведено детальний алгоритм розрахунку еквівалентного значення коефіцієнту теплопровідності деревного масиву. На основі зазначених досліджень підтверджено дочільність застосування нового підходу, який дозволяє врахувати величину впливу радіаційної складової на сукупне значення ефективної теплопровідності композитно-пористого матеріалу.
\end{abstract}

Ключові слова: деревне вугілля, піроліз, конвекційний теплообмін, коефіцієнт теплопровідністі, композитна пористость, газовий прошарок.

\section{STUDY OF THE RADIATION COMPONENT INFLUENCE ON THE EFFECTIVE HEAT CONDUCTIVITY OF COMPOSITE-POROUS BUNDLE}

\author{
Tovazhnyanskyy L. L., Dr. Sci., professor; Ved V. YE., Dr. Sci., professor, Myronov A. M., Ph.D.
} National Technical University «Kharkiv Polytechnic Institute», Kharkiv

\begin{abstract}
The paper deals with a number of issues related to the heat exchange processes which occur in industrial charring plants. The research is aimed to finding a calculation algorithm that can equivalently take into account the influence of the composite-porous body structure on the thermal conductivity coefficient of a bundle formed by wood logs in a trolley' space. It is shown that the phenomenological model of the heat conductivity process, which is based on the concept of solids continuity, is not suitable for use in the context of calculating the degree of material porosity contribution to its thermal conductivity. It is specified that such a model ignores not only the structural content of real materials, but also the possibility of forming anisotropic cluster formations in their thickness. It is found that simplification of the microscopic structure is not allowed for a wooden bundle that takes part in the charcoal production using pyrolysis method. There are analyzed several methods of wooden raw materials loading into a trolley and a percentage of volume that can be usefully used in each of them. The most technologically and operationally expedient way of wooden raw materials loading is chosen. A well-known calculation model, which is based on the equable solid phase distribution along the boundaries of structural element, is considered. It is established that this model demonstrates results that do not correspond to physical reality for the boundary values. The reasons of model inadequacy to real objects are revealed on the example of a wooden log bundle. An improved calculation model, which involves replacing the linear contact between the elements to the surface one, is presented. There are considered the artificial conditions of the calculated assumption that an infinitely thin material layer is located along the boundaries of a structural element, and the entire material mass is centered in the form of a square-section object. There is given
\end{abstract}


a detailed algorithm for calculating the equivalent value of the wooden bundle thermal conductivity coefficient. The appropriateness of applying a new approach is confirmed based on these studies, which allows taking into account the magnitude of the radiation component effect on the total value of the effective thermal conductivity of composite-porous material.

Keywords: charcoal, pyrolysis, convective heat transfer, coefficient of thermal conductivity, composite porosity, gas layer.

Вступ. Виробництво деревного вугілля піролізним способом в установках сучасних конструкцій потребує детального аналізу кожного з технологічних переділів та створення відповідного апаратурного забезпечення процесу. Це накладає певні обмеження з суто технічних та геометричних міркувань, що має бути неодмінно враховано при проектуванні більш нового обладнання або модернізації існуючого. Надалі комплексно розглядатиметься не тільки проблема завантаження деревинної сировини у вагонетки прямокутної конструкції, але й аналізуються показники явищ, що супроводжують та власне забезпечують процеси теплообміну в матеріалі при використанні раціонального способу розміщення деревних полінець.

При проведенні досліджень з оптимізації руху теплових потоків у вагонетках найбільша увага повинна приділятися принципам урахування геометричної складової масиву, сформованого сировинними полінцями. У даному випадку нема можливості розглядати такий масив ані як цільне пористе тіло зі встановленим коефіцієнтом пористості, ані як сукупність окремих елементів із завчасно відомими характеристиками, придатними для узагальнення.

Перш за все необхідно визначити ключовий показник, спираючись на який можна оцінити вплив структури початкового матеріалу на теплові процеси у апараті піролізу та, як наслідок, й на якість кінцевої продукції. Таким показником $є$ коефіцієнт теплопровідності масиву сировини, який визначає передумови для визначення швидкості передачі тепла та ії рівномірності у товщі матеріалу.

Формулювання проблеми та аналіз останніх досліджень. Відома нині феноменологічна модель процесу теплопровідності, яка базується на концепції суцільності твердих тіл, здібних зберігати свої властивості в безкінечно малому об'ємі, ігнорує не тільки структурну будову реальних матеріалів, але й можливість формування анізотропних кластерних утворень в їх товщі. Якщо для деяких матеріалів інколи дійсно припускається спрощення мікроскопічної структури, то для деревини нехтувати цим явищем неможливо. Оскільки розмір будь-якої реальної сировини, яка використовується для виробництва деревного вугілля, на багато порядків перевищує діаметр волокнини та мікропор, навіть при виконанні оціночних розрахунків необхідно коректно враховувати пористість самої деревини $[1,2]$.

При цьому слід пам'ятати, що в контексті теплових процесів властивості, виражені коефіцієнтами, $\epsilon$ величинами, які отримувались здебільшого емпіричним шляхом, а згодом підтверджувались розрахунково. Тобто найчастіше такі значення визначають, співставляючи результати експериментів, проведених на макрозразках, з результатами, які витікають з відомих раніше феноменологічних рівнянь, що автоматично забезпечує надійність отриманих значень для тіл з макроскопічними розмірами. Проте, за мірою наближення розмірів тіл до розмірів їх структурних елементів надійність знайдених в такий спосіб значень зменшується. Деревина, як будь-який інший волокнистий матеріал, має свою власну, природну, пористість. У вагонетках вона фактично формує нове фізичне тіло - щільний масив (пакет), завдяки чому матеріал набуває нової властивості - композитної пористості [1-4].

Навіть за умови відсутності у такому тілі анізотропії теплопровідних властивостей, для успішного застосування будь-якої з існуючих феноменологічних моделей до реальних тіл необхідно, аби їх розміри багатократно перевищували розміри відповідних структурних елементів. Очевидно, що в композитнопористих тілах утворюється дворівнева ієрархія, де першу пару макрорівень-мікрорівень складають пакет дерев'яних полінець та проміжки між полінцями в якості "пор", а другу - безпосередньо кожне одиничне поліно та його внутрішня волокниста будова $[1,5]$.

Найбільш природнім рішенням для узагальнення особливостей верхнього рівня згаданої ієрархії буде поширення моделі суцільності твердих тіл на випадок деревних полінець як слабко неоднорідних матеріалів, які мають прийнятний порядок різниці між мікро- та макрорівнем. Розглядаючи спосіб завантаження сировини в вагонетку можна відзначити кількісно та якісно впорядковану структуру, геометричні параметри якої завжди відомі завчасно. Таким чином досягається можливість розрахувати феноменологічні коефіцієнти для масиву сировини, спираючись на встановлені значення цих коефіцієнтів для структурних елементів та їхної геометрії.

Результати та їх обговорення. Найбільш природнім рішенням для узагальнення особливостей верхнього рівня згаданої ієрархії буде поширення моделі суцільності твердих тіл на випадок деревних полінець як слабко неоднорідних матеріалів, які мають прийнятний порядок різниці між мікро- та макрорівнем. Розглядаючи спосіб завантаження сировини в вагонетку можна відзначити кількісно та якісно впорядковану структуру, геометричні параметри якої завжди відомі завчасно. Таким чином досягається можливість розрахувати феноменологічні коефіцієнти для масиву сировини, спираючись на встановлені значення цих коефіцієнтів для структурних елементів та їхньої геометрії. 
Застосування цього підходу до задач визначення супроводжуючих теплофізичних параметрів в контексті нагріву пористих тіл призвело до необхідності введення терміну «еквівалентна теплопровідність композитно-пористого масиву». Величина цього параметру дозволяе в рамках досить простої моделі аналізувати результат складного комплексу теплообмінних процесів, включаючи не тільки теплопровідність, але й конвекційний теплообмін крізь газові прошарки, які утворено полінцями. Фактично вона дозволяє на основі експериментальних даних розрахунковим шляхом визначити цільові теплофізичні характеристики як в поздовжньому, так і в поперечному напрямку відносно орієнтації волокнини матеріалу.

Під час розрахунків слід взяти до уваги наявність наступних п'яти аспектів:

- присутність теплового контактного опору на границях твердої і газової фаз;

- значної різниці в значеннях теплопровідності твердої та газової фаз (на кілька порядків);

- газові прошарки $є$ досить великими і не вважаються оптично тонкими, а тверда фаза $є$ фактично непрозорою для випромінювання;

- вплив наявного в прошарках газу конвективного теплообміну має бути коректно врахованим у загальних розрахунках;

- наявність припущення про те, що пакет полінець має відкриту пористість [2, 5].

Виходячи з положення про однакову направленість волокон в полінах та полінець в пакеті, обчислити еквівалентну теплопровідність для композитно- пористого матеріалу легше, якщо розглядати структуру як повторюваний кластер. Наприклад, для тіл з геометрією наближеною до циліндру (поліно) в пакеті існує декілька принципів укладання, два з яких зображено на рис. 1.

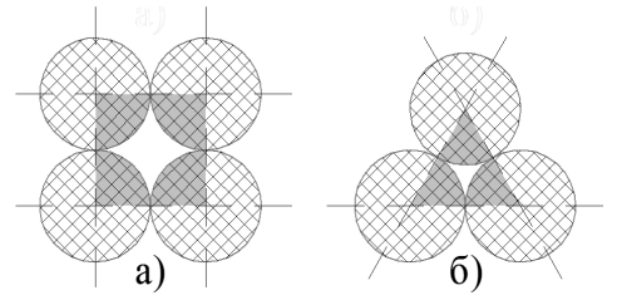

Рис. 1. Схема щільного укладання полінець в пакет.

Пористість варіанту а) складає приблизно 21,5\% від загальної площі (а для циліндру, відповідно, й від об’єму). Варіант б) є найбільш економним з усіх фізично можливих, але тільки для структур з числом елементів, кратним трьом, та/або трикутних форм він забезпечує пористість біля $11 \%$. Однак цілком зрозуміло, що вагонетка будь-якої конструкції для завантаження буде прямокутною, а в такому разі пористість складатиме щонайменше $26,7 \%$. Це $є$ неприйнятним не тільки 3 кількісної точки зору, але й з огляду на малу зручність експлуатації вагонеток в промислових масштабах. Таким чином, вибір робиться на користь варіанту а), який визнано оптимальним для досягнення поставлених технологічних, виробничих та експлуатаційних цілей.

Необхідно обрати усереднений схемно-структурний варіант, який міг би утворитися за умови рівномірного розподілу матеріалу в перетині пакету. Для визначення еквівалентної теплопровідності подібний варіант являє собою достатньо складний об'єкт, тому його слід замінити придатною для розрахунків моделлю. Вибір цієї моделі визначатиме те, наскільки просто буде формулюватися сукупна задача, з одночасним збереженням ключових особливостей прототипу.

Для пакета типових циліндричних об’єктів відома структура, згідно якої тверда фаза є рівномірно розподіленою уздовж меж структурного елементу (рис. 2) [5]. При цьому розрахунок зводиться до сумування провідності ділянок 3-6, що відносяться до зони $B$, а потім до сумування теплових опорів послідовно розташованих ділянок $A$ та $B$ [5].

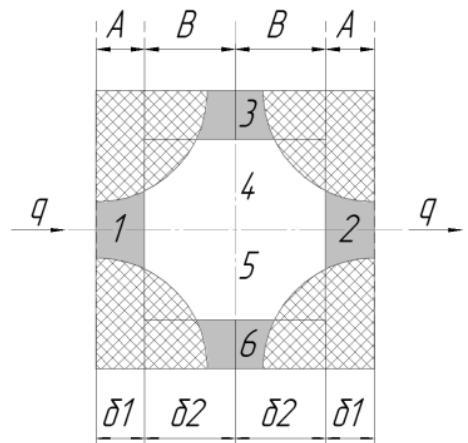

Рис. 2. Розрахункова модель структури рівномірного розподілу твердої фази за об'ємом.
В результаті отримується рівняння наступного виду:

$$
\lambda_{\text {екв }}=\left[\frac{\delta_{1}}{\lambda_{\text {мат }} \cdot\left(\delta_{1}+\delta_{2}\right)}+\frac{\delta_{2}}{\lambda_{\text {мат }} \cdot \delta_{1}+\lambda_{\text {газ.пр }} \cdot \delta_{2}}\right]^{-1}
$$

де $\lambda_{\text {екв }}$ - еквівалентна теплопровідність, Вт/(м·K);

$\delta_{1}$ та $\delta_{2}$ - товщина відповідних ділянок матеріалу, м;

$\lambda_{\text {мат }}$ - теплопровідність матеріалу, Вт/(м·K);

$\lambda_{\text {газ.пр }}$ - теплопровідність газового прошарку, Вт/(м·K).

Спираючись на рівняння теплового потоку, спрямованого нормально до поверхні елементів пакету за стаціонарних умов та без врахування конвективної складової величиною

$$
q=\frac{\Delta t}{\frac{\delta_{\text {мат }}}{\lambda_{\text {мат }}}+\frac{S}{\alpha \cdot S+\lambda_{\text {газ }}}},
$$

де $q$ - тепловий потік, Вт;

$\Delta t$ - різниця температур в двох подібних співвісних точках сусідніх елементів матеріалу, К; 
$\delta_{\text {мат }}-$ товщина матеріалу, м;

$\alpha$ - коефіцієнт тепловіддачі випромінюванням, Вт/м².К;

$S$ - товщина прошарку газу, м;

$\lambda_{\text {газ }}$ - теплопровідність газу, Вт/(м·K),

можна перейти до величини еквівалентної теплопровідності газового прошарку

$$
\lambda_{\text {газ.пр }}=\alpha \cdot S+\lambda_{\text {газ }}
$$

Для спрощення обрахунку та універсалізації результатів вводяться безрозмірні величини:

$$
\begin{aligned}
& \psi=\lambda_{\text {екв }} / \lambda_{\text {мат }}, \\
& \Lambda=\lambda_{\text {газ. пр }} / \lambda_{\text {мат }}, \\
& \gamma=\delta_{2} /\left(\delta_{1}+\delta_{2}\right) .
\end{aligned}
$$

Звідси можна перейти до цільового співвідношення між значенням еквівалентної теплопровідності та власне теплопровідністю матеріалу такого вигляду [5]:

$$
\psi=\frac{1-\gamma \cdot(1-\Lambda)}{1-\gamma \cdot(1-\gamma) \cdot(1-\Lambda)} .
$$

На жаль, для структури, подібної пакету деревних полінець, коли останні виступають «волокнами» системи, ця формула може давати нелогічні результати. Наприклад, при межовому заданні $(\Lambda=0)$ тобто при умовному вакуумі в проміжках та за відсутності випромінювання за формулою (5.18) отримуються значення $\psi$, які дорівнюють не нулю, як було б логічним, а різні величини для різної пористості, в тому числі, близькі до одиниці (наче $\lambda_{\text {екв }} \approx \lambda_{\text {мат }}$ ). Причина в тому, що в [5] розрахункова модель не адекватна реальним об'єктам. Принциповою відмінністю є той факт, що на ділянках А розрахункової моделі (рис. 2) лінійний контакт між полінцями в пакеті (коли поверхня контакту вздовж лінії дорівнює нулю) замінено на поверхневий контакт. Площа контактної поверхні складає від загальної площі, крізь яку проходить потік тепла частку, що дорівнює $1-\rho$, де $\rho$ - це пористість.

Для пакету дерев'яних полінець пропонується застосовувати розрахункову модель, яка зображена на рисунку 3. Пунктиром зображено структуру пакету, «волокнами» якого виступають дерев'яні полінця. Загальна площа перетину структурного елемента розрахункової моделі дорівнює площі перетину структурного елемента реального тіла. Безкінечно тонкий прошарок матеріалу розташований уздовж меж структурного елементу, а уся маса матеріалу зосереджена в центрі в вигляді об'єкту квадратного перетину. Тепер для межового випадку коли $\lambda_{\text {газ }}=0$ та $\alpha=0$, модель показує логічний результат: $\lambda_{\text {екв }}=0$. 3 іншого боку, якщо умови теплопередачі крізь прошарки газу стануть сприятливими, наявність безкінечно тонких екранів вздовж границь структурних елементів розрахункової моделі буде запобігати похибці, яка пов'язана з некоректною оцінкою ролі радіаційного теплообміну.

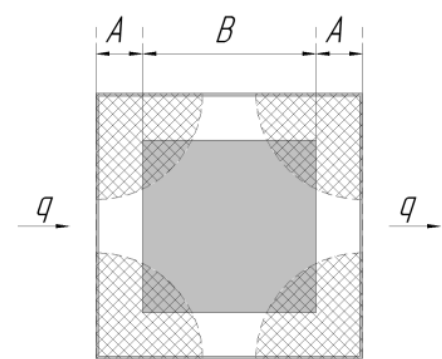

Рис. 3. Вдосконалена розрахункова модель структури розподілу твердої фази за об'смом.
Разом $з$ тим необхідно відзначити: модель, яка зображена на рис. 3, має певну незручність через те, що товщина газових прошарків за напрямом теплового потоку на ділянках $A$ та $B$ неоднакова, і кожна 3 цих ділянок має своє власне значення $\lambda_{\text {газ.пр }}$ Розрахунок можна значно спростити, якщо еквівалентну теплопровідність для ділянок $A$ та $B$ визначити окремо, а потім просумувати отримані результати, буквально враховуючи коефіцієнти пропорційності, згідно виразу

$$
\lambda_{\text {екв }}=\lambda_{\text {мат }} \cdot(1-\rho)+\lambda_{\text {газ }} \cdot \rho,
$$

де $\rho$ - пористість пакету.

Повний алгоритм розрахунку буде таким, як наведено далі.

1. Пористість для ділянки $A$ приймається $\rho_{A}=1$.

2. Пористість для ділянки $B$ обчислюється як

$$
\rho_{B}=1-\sqrt{1-\rho} .
$$

3. Загальний розмір структурного елементу дорівнює товщині газових прошарків на ділянках $A$ :

$$
S_{B}=\frac{d}{2} \cdot \sqrt{\frac{\pi}{1-\rho}},
$$


де $d$ - діаметр полінець в пакеті.

4. Сумарна товщина двох газових прошарків на ділянці В становить:

$$
S_{B}=\frac{d}{2} \cdot \sqrt{\frac{\pi}{1-\rho}} \cdot(1-\sqrt{1-\rho}) .
$$

5. Відносна теплопровідність газових прошарків дорівнює:

$$
\begin{aligned}
& \Lambda_{A}=\frac{\alpha \cdot S_{A}+\lambda_{\text {газ }}}{\lambda_{\text {газ }}}, \\
& \Lambda_{B}=\frac{\alpha \cdot S_{B}+\lambda_{\text {газ }}}{\lambda_{\text {мат }}} .
\end{aligned}
$$

6. Очевидно, що ділянки композиту $A$ та $B$ мають різну структуру та слоїсту пористість, тому відносну теплопровідність для них визначається з наступного рівняння [5]:

$$
\psi=\frac{\Lambda}{\Lambda+\rho \cdot(1-\Lambda)}
$$

7. Підстановка в отримане рівняння (14) аналітичних вирази (12) та (13) дає змогу отримати:

$$
\begin{gathered}
\psi_{A}=\frac{\Lambda_{A}}{\Lambda_{A}+\rho_{A} \cdot\left(1-\Lambda_{A}\right)}=\Lambda_{A}, \\
\psi_{B}=\frac{\Lambda_{B}}{\Lambda_{B}+\rho_{B} \cdot\left(1-\Lambda_{B}\right)}=\frac{\Lambda_{B}}{\Lambda_{B}+(1-\sqrt{1-\rho}) \cdot\left(1-\Lambda_{B}\right)},
\end{gathered}
$$

8. Сумування за формулою (8) та виконання очевидних математичних перетворювань дозволяє отримати вираз наступного виду:

$$
\psi=\psi_{A} \cdot(1-\sqrt{1-\rho})+\psi_{B} \cdot \sqrt{1-\rho} .
$$

Наведені вище результати підтверджують можливість врахування еквівалентних часток усіх задіяних у процесі теплообміну зон.

\section{Висновки}

В роботі наведено алгоритм, який дозволяє еквівалентно врахувати вплив структури композитнопористого тіла на коефіцієнт теплопровідності масиву не виходячи за межі розрахункової моделі. Наразі показано новий підхід, що більше спрямований на розгляд нетрадиційної для подібних розрахунків радіаційної складової, внесок якої $є$ набагато меншим, ніж внесок конвекції за таких розмірів матеріалу. Але не враховувати його значущість не можна, оскільки відсоток відхилення величини теплового потоку в теплових процесах через нехтування випромінюванням в окремих випадках може складати від 5 до $25 \%$ від загального. Спираючись на це, можна зробити висновок про необхідність дослідження теплообміну для нерухомих станів, де разом з конвективним переносом враховуватиметься також і передача тепла теплопровідністю в прошарках матеріалу. Можливість застосування викладеної методології для різного масштабу елементів, які формують подібні пакети, повинна буди перевірена ситуативно, виходячи з низки структурно-хімічних, геометричних та фізичних параметрів досліджуваних зразків.

Оскільки комплекс теплових процесів та явищ, які відбуваються всередині вагонетки для піролізу деревини, $є$ досить складним, треба зважати не тільки на теплообмінні, але й на аеродинамічні процеси в закритому просторі. Належна конструкція вагонетки має забезпечувати ефективну циркуляцію гарячого газу, завдяки якому стане можливим найбільш економічно вигідна інтенсифікація процесу піролізу деревної сировини.

\section{Література}

1. Ведь В. Є., Миронов А. М. Дослідження зв’язку між структурою деревини та кінетикою процесу їі сушки / Вісник Національного технічного університету «ХПІ», 2015. № 44 (1153). С. 47-51.

2. Литовченко Ю. К. Теплопроводность пористых тел. / Металлургическая теплотехника. Сборник научных трудов Национальной металлургической академии Украины. Том 9. Днепропетровск: НМетАУ, 2003. 197 с.

3. Юрьев Ю. Л. Совершенствование производства углеродных материалов на основе берёзовой древесины: диссертация на соискание учёной степени кандидата физико-математических наук: специальность 05.21 .03 «Технология и оборудование химической переработки биомассы дерева; химия древесины». Екатеринбург: Уральский государственный лесотехнический университет, 2014. $256 \mathrm{c}$.

4. Myronov A., Ved V. Determination of rational parameters for energy efficient drying process of different wood species / Тези доповідей Міжнародної науково-практичної конференції Computer Aided Process Engineering (CAPE). Paderborn, Germany: CAPE Forum 2015, 2015. PP. 67-69.

5. Тайц Н. Ю. Технология нагрева стали/ М.: Металлургиздат, 1962. 567 с.

References

1. Ved, V. E., Myronov, A. M. (2015). Doslidzhennya zv'yazku mizh strukturoyu derevini ta kinetikoyu protsesu yiyi sushki. Visnik Natsionalnogo tehnichnogo universitetu «HPI», 44 (1153), 47-51.

Наукові праці, Том 82, випуск 1 Scientific Works, Volume 82, Issue 1 
2. Litovchenko, Yu. K. (2003). Teploprovodnost poristyih tel. Metallurgicheskaya teplotehnika. Sbornik nauchnyih trudov Natsionalnoy metallurgicheskoy akademii Ukrainyi, vol. 9. Dnepropetrovsk: NMetAU, 197.

3. Yurev, Yu. L. (2014). Sovershenstvovanie proizvodstva uglerodnyih materialov na osnove beryozovoy drevesinyi: phD thesis. Ekaterinburg: Uralskiy gosudarstvennyiy lesotehnicheskiy universitet, 256.

4. Myronov, A., Ved V. (2015). Determination of rational parameters for energy efficient drying process of different wood species. Computer Aided Process Engineering (CAPE). Paderborn, Germany: CAPE Forum 2015, 67-69.

5. Tayts, N. Yu. (1962). Tehnologiya nagreva stali. M.: Metallurgizdat, 567.

Отримано в редакцію 22.04.2018

Прийнято до друку 30.06.2018
Received 22.04.2018

Approved 30.06.2018

\title{
ВОЗДЕЙСТВИЕ ГИДРОДИНАМИЧЕСКОЙ КАВИТАЦИИ НА БИОЛОГИЧЕСКИЕ КЛЕТКИ. МЕХАНИЗМЫ, ТЕХНОЛОГИИ, ПРИМЕНЕНИЕ
}

\author{
Гоженко Л.П., к.т.н., Недбайло А.Е., к.т.н., Иваницкий Г.К., д.т.н. \\ Институт технической теплофизики НАН Украины, г. Киев
}

\begin{abstract}
Аннотация. Целью данной работы является раскрыть механизмы воздействия кавитации на биологические клетки для создания новых технологий и оборудования, а также усовершенствования уже существующих. Анализ современной литературы показал, что процесс кавитаџии широко используется в пищевой, химической, фармацевтической, биологической промышленности и является эффективным с экологической, энергетической точки зрения. При этом, сточт отметить, что использования кавитации в технологиях существенно сокращует время ведения процесса обработки, а также минимизирует температурное воздействие, по сравнению с традиционными технологиями, что особенно актуально при работе с биологически-активными веществами. Кавитаџионные процессы используются в технологиях экстракции растительного сырья, стерилизаџии жидкостных сред как в пищевой промышленности, так и в технологиях водоподготовки и водоочистки. Не смотря, на то, что кавитацию широко применяют на практике, литературный анализ показал, что механизмы воздействия на клетки изучень не в полной мере. В статье предложены механизмы и их теоретическое обоснование для процесса экстракции и стерилизации, определены теплофизические параметры необходимые для ведения того или иного процесса. В зависимости от сферы применения кавитации ее интенсивность и механизм воздействия должны определяться свойствами целевого продукта. Соответственно, для отдельных иелей параметры ведения процесса должны обеспечить полное разрушение клетки, а для других необходимо и достаточно повысить проницаемость мембраны клетки для выхода целевого компонента. В связи с этим, существует необходимость тонкого подбора теплофизических параметров процесса, а также технологического оборудования, соответственно.
\end{abstract}

Ключевые слова: кавитация, экстракция, стерилизация, биологические клетки

\section{THE INFLUENCE OF HYDRODYNAMICAL CAVITATION ON BYOLOGICAL CELLS. MECHANISMS, TECHNIQUES, APPLICATION}

\author{
Gozhenko L. P., PhD, Nedbailo A. Y., PhD, Ivanytskiy G. K., DSc. \\ Institute of Engineering Thermophysics of NAS of Ukraine., Kyiv
}

\begin{abstract}
The purpose of this work is to found the mechanisms of the effect of cavitation on biological cells for the creation of new technologies and equipment, as well as the improvement of existing ones. Analysis of present literature has shown that the process of cavitation is widely used in the food, chemical, pharmaceutical, and biological industries and is effective from an ecological, energy point of view. At the same time, it should be noted that the use of cavitation in technologies significantly reduces the processing time, as well as minimizes the temperature effect, in comparison with traditional technologies, which is especially important for biologically active substances. Cavitation processes are used in technologies of extraction of plant raw materials, sterilization of liquid media both in the food industry, and in technologies of water treatment and water purification. Despite the fact that cavitation is widely used in practice, literary analysis has shown that mechanisms of action on cells have not been fully studied. Novel studies presents mechanisms, which ascertain fact of cell wall full or partially distruction, but not explain reasons of this. There is not explaining of the decrease in internal massexchange resistances. The article proposes mechanisms and their theoretical justification for the extraction and sterilization process, and the thermophysical parameters necessary for conducting a particular process are determined.
\end{abstract}

